\title{
THE VACUUM ASSISTED CLOSURE OF COMPLEX WOUNDS: REPORT OF 3 CASES
}

\author{
Marcus Castro Ferreira, Alexandre Wada, and Paulo Tuma Jr.
}

FERREIRA MC et al. - The vacuum assisted closure of complex wounds: report of 3 cases. Rev. Hosp. Clín. Fac. Med. S. Paulo 58(4): 2003.

Treatment of wounds using conventional methods is frequently limited by inadequate local wound conditions, or by a poor systemic clinical situation. Vacuum system may promote faster granulation tissue formation, remove excessive exudate, increase blood flow in the wound, and attract the borders of the wound to the center, reducing its dimension. We present 3 cases of patients with difficult wounds, due to bad local conditions, or poor clinical situation, in whom we used a vacuum system to prepare the wound for the surgical closure. One patient had a pressure ulcer, another had a diabetic foot ulcer, and the third one had an open foot stump. In the 3 cases a significant improvement of the wound conditions was achieved after 7 to 8 days, allowing successful surgical treatment with flap or skin grafts.

DESCRIPTORS: Wound. Healing. Vacuum. Surgery.

Chronic exudative wounds are frequent problems in hospitalized patients, responsible for increased costs and high morbidity, demanding complex resources for their treatment. $\mathrm{Pa}$ tients restricted to bed, with unstable conscience level and associated diseases, present delayed formation of granulation tissue, lesser contraction of the wound, and increased local bacterial population. Healing is impaired, adding hospitalization time, causing discomfort and pain.

Treatment includes surgical and non surgical procedures. Surgical procedures are usually the most efficient, leading to faster wound healing. They include debridements and wound cover, using skin grafts or flaps. However, in some cases, when no adequate clinical conditions are present or when the quality of the wound is not ideal, non surgical procedures may be necessary to prepare the wound for defini- tive surgical treatment. Wound cleaning, chemical debridements and many types of dressing are the usual procedures, but they usually extend the time of hospital stay or ambulatory care. Moreover, there is no agreement about the best dressing for exudative wounds; there are only evidences of individual advantages of a specific one concerning some specific characteristic.

The use of a vacuum system (Vacuum-Assisted Closure - VAC ${ }^{\circledR}$ KCI, USA) to help wound healing was introduced in 1997 by Argenta et al. ${ }^{1,2,3}$, and consists of an hydrophobic sponge, connected to a device that produces a negative pressure on the

From the Division of Plastic Surgery, Faculty of Medicine, University of São Paulo - São Paulo/SP, Brazil.

Received for publication on January 22, 2003. system and over the wound (Figs. 1A e 1B). Negative pressure seems to promote drainage of excessive fluids from the wound bed and interstitial space, reducing bacterial population and edema, and to enhance local blood flow and granulation tissue formation. Other effect of vacuum is to pull of the wound borders to the center, reducing the wound diameters due to retraction.

Surgeons believe that the treatment of difficult wounds should be primarily surgical, and the VAC system was reported to accelerate the preparation of the wound to definitive surgical closure. In other words, it improves the local conditions in patients who are waiting a better clinical situation to be submitted to surgical procedures or, in the specific case of pressure ulcers, reduces the ulcer surface, making it possible to perform smaller flaps, with less undermining, and reduction on the size of the operation. 
For infected wounds, the use of vacuum dressing would reduce pyogenic exudate, making possible the closure with a skin graft.

With these concepts in mind, we introduced in our service, in 2002, the method of vacuum assisted closure. The system was used to treat 3 difficult wounds, especially pressure ulcers and diabetic foot ulcers, thus preparing them to definitive surgical closure. The vacuum treatment aimed also to improve the take of skin grafts.

We are conducting a clinical trial on this subject. However, as our first impression was quite positive, and there is no previous report on the use of this new technique in our country, we decided to report this initial experience.

\section{CASE REPORTS}

\section{CASE 1}

A 60 year-old male diabetic was admitted with infection on the lateraldorsal aspect of left foot, with skin necrosis (Fig. 2A). He was submitted to surgical debridement with removal of a large amount of necrotic tissue (Fig. 2B). VAC ${ }^{\circledR}$ was installed on June 3, 2002. Local conditions improved, as observed even in the first change of dressing. On the seventh day, the granulation tissue was adequate to support a split thickness skin graft (Fig. 2C), which resulted in total healing of the wound. (Fig. 2D).

\section{CASE 2}

A 56 year-old male diabetic, with sensitive deficit in the feet, had a transmetatarsal amputation of the right foot and presented a wound with secondary infection and necrotic tissue, moderate exudate and an exposed bone (Fig. 3A). VAC $^{\circledR}$ was installed on September 9, 2002, in an attempt to improve the wound conditions, allowing coverage of the bone, and thus to shorten the time for definitive skin grafting (Fig. 3B). A meshed skin graft was applied on the seventh day (Fig. $3 \mathrm{C}$ ), and the vacuum technique was used again, in order to fix it. Complete take of skin graft was achieved, and the patient was discharged 4 days afterwards with his wound totally healed (Fig. 3D).

\section{CASE 3}

A ninety year-old woman, with systemic arterial hypertension and chronic renal failure, was admitted with an aspirative pulmonary infection and sepsis. She developed a grade IV sacral ulcer. The ulcer was surgically debrided (Fig. 4A), and, after 2 days, the $\mathrm{VAC}^{\circledR}$ was installed (April 3, 2002) (Fig. 4B). After 8 days of vacuum treatment (Fig. 4C), surgical closure was provided by an unilateral V-Y gluteal flap (Fig. 4D). The outcome was successful, with complete resolution of the problem.
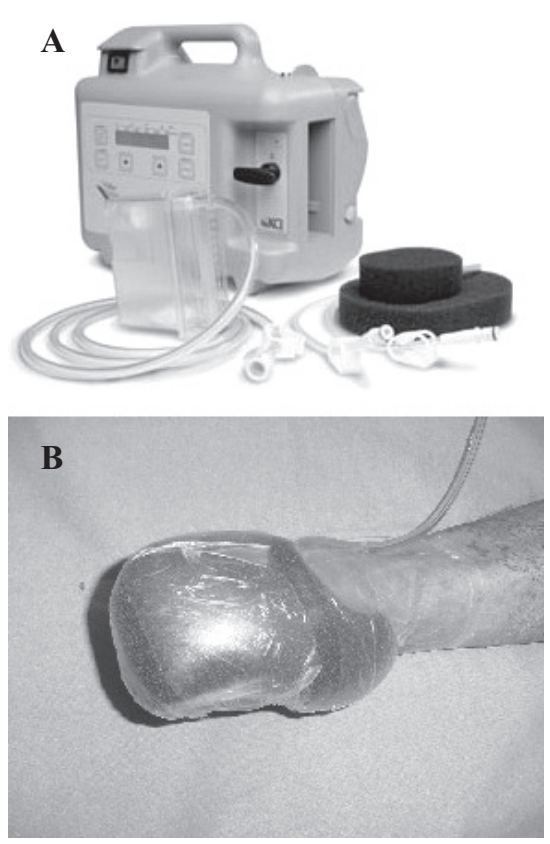

Figure 1 - A: Vacuum-assisted closure device; B: Vacuum-Assisted Closure used for fixation of skin graft.
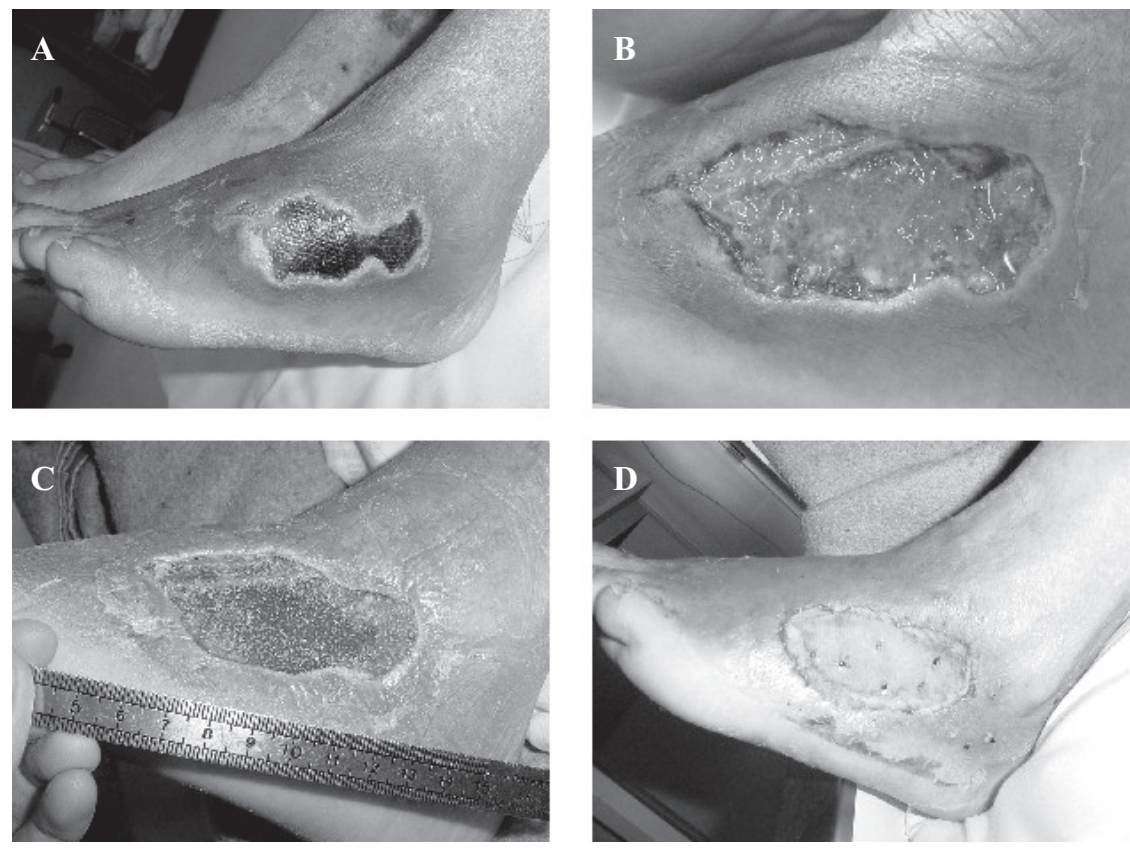

Figure 2 - Case 1 - A: Infection of diabetic foot; $\mathbf{B}$ : Wound after skin debridement of necrotic tissue; C: Seventh day of vacuum therapy; D: Aspect one week after skin graft. 

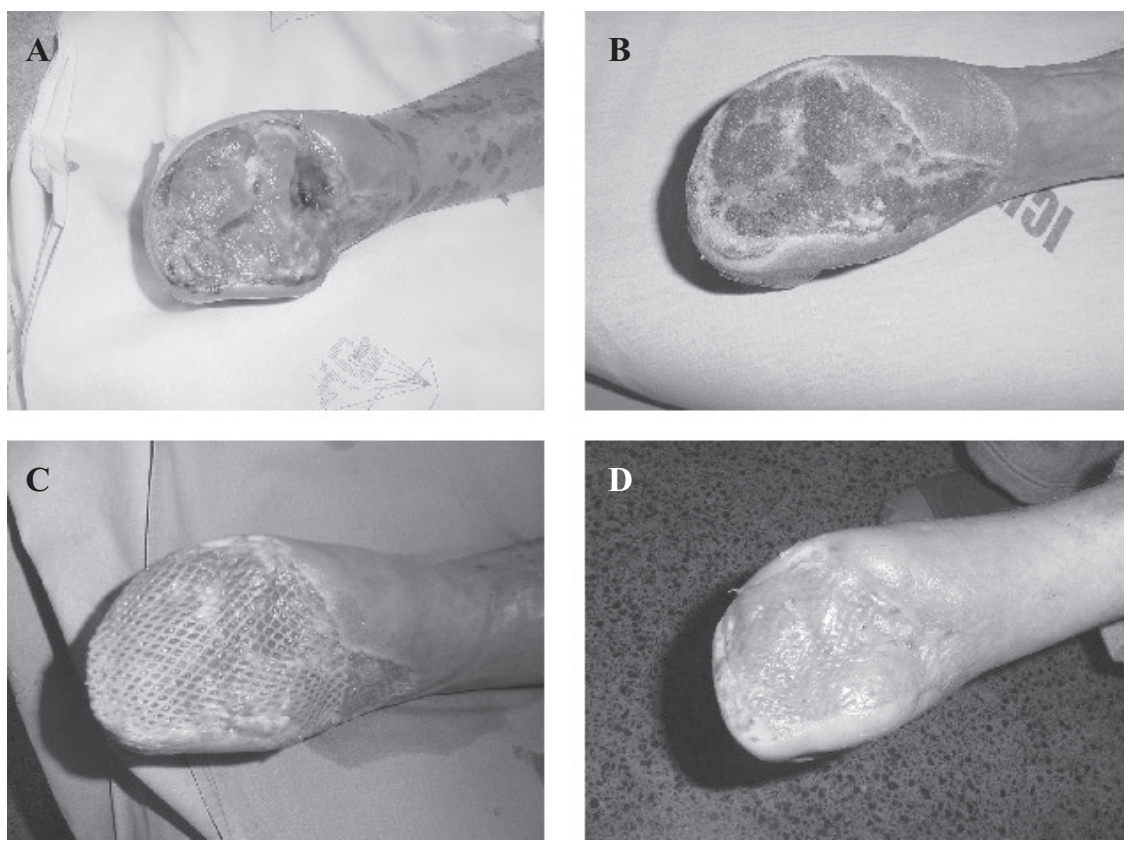

Figure 3 - Case 2 - A: Wound resulted of transmetatarsal amputation; B: Aspect 7 days after vacuum therapy; C: Meshed skin graft applied; D: Result thirty days after skin graft.
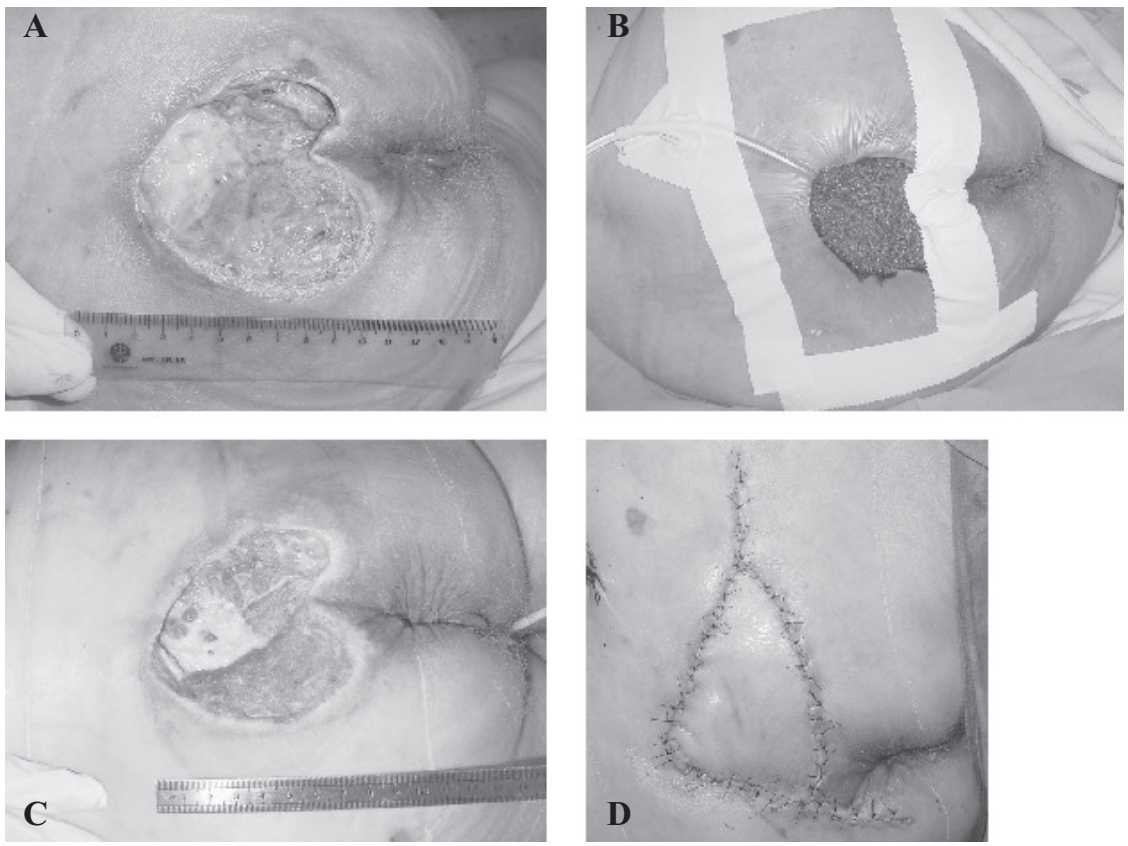

Figure 4 - Case 3 - A: Sacral ulcer, grade IV; B: Vacuum-Assisted Closure installed; C: Aspect 8 days after vacuum therapy; D: V-Y gluteal flap closed the wound.

\section{RESUMO}

FERREIRA MC e col. - Tratamento de feridas complexas utilizando sistema a vácuo: relato de três casos. Rev. Hosp. Clín. Fac. Med. S. Paulo 58(4):227-230, 2003.
O tratamento de feridas através de métodos convencionais é, muitas vezes, limitado por condições locais inadequadas, ou por comprometimento das condições clínicas do paciente. O uso de sistema de vácuo teria como vantagens aumentar a velocidade de formação de tecido de granulação, remover secreções da ferida, aumentar o fluxo sangüíneo local, e atrair as bor- 
das da ferida ao centro, reduzindo suas dimensões. Apresentamos três casos de pacientes com diferentes feridas de difícil tratamento, devido a más condições locais ou a condições clínicas desfavoráveis, nos quais usamos um sistema de vácuo a fim de preparar a ferida para fechamento definitivo. Um deles apresentava úlcera de pressão, outro uma úlcera em pé diabético, e o terceiro um coto de amputação de pé com área cruenta. Nos três casos uma melhora importante das condições das feridas foi obtida em sete a oito dias, permitindo o tratamento cirúrgico bem sucedido com retalho ou enxertia de pele.

DESCRITORES: Cicatrização. Ferida. Vácuo. Cirurgia.

\section{REFERENCES}

1. ARGENTA LC, MORIKWAS MJ - Vacuum-assisted closure: a new method for wound control and treatment: clinical experience. Ann Plast Surg 1997; 38 (6): 563-76.

2. MORIKWAS MJ, ARGENTA LC, SHELTON-BROWN EI et al. Vacuum-assisted closure: a new method for wound control and treatment: animal studies and basic foundation. Ann Plast Surg 1997; 38 (6): 553-62.
3. De FRANZO AJ, ARGENTA LC et al. - The use of vacuumassisted closure therapy for the treatment of lower-extremity wounds with exposed bone. Plast Reconstr Surg 2001; 108 (5): 1184-91. 